Acta vet. scand. $1968,9,199-207$.

From the Department of Medicine II and the Department of Medicine I, Royal Veterinary College, Stockholm, Sweden.

\title{
THE INFLUENCE \\ OF A »FLUSHING DOSE« OF SELENIUM ON THE EXCRETION OF SELENIUM \\ IN SHEEP*)
}

By

S. O. Jacobsson and P. Lindberg

The uptake of orally or parenterally administered $\mathrm{Se}^{75}$-selenium is high in the kidneys (McConnell 1941, Orstadius \& Aberg 1961, Ekman et al. 1963, Jacobsson 1966). The distribution patterns and absolute amounts of retained selenium in pigs were not consistently affected by the duration of sodium selenite supplementation $(0.2 \mathrm{mg} / \mathrm{kg}$ diet from 13 to 367 days $)$ or by the length of the selenium-free period before slaughter (Grant et al. 1961). Lindberg \& Lannek (1965) and Lindberg \& Tanhuanpää (1965) could not demonstrate any increase of selenium in the kidneys of pigs, which had received sodium selenite orally (1.2 p.p.m. Se in the food) or parenterally $(0.06 \mathrm{mg}$ Se per $\mathrm{kg}$ body weight intramuscularly) as compared with pigs given food containing $126 \mathrm{ng}$ Se per g.

These seemingly contradictory reports support the assumption that part of the stored selenium in the body is "flushed out" by the administered selenium. Strontium (Spencer et al. 1961) and vitamin $B_{12}$ (Shilling 1953, Flodh 1967) have been shown to behave in this way.

\section{MATERIAL AND METHODS}

$\mathrm{Se}^{75}$-sodium selenite and $\mathrm{Se}^{75}$-L-selenomethionine were obtained in aqueous solution from the Radiochemical Centre, Amersham, England. Non-radioactive sodium selenite in aqueous

*) This investigation was supported by a grant from the Swedish Agricultural Research Council. 
solution was placed at our disposal by AB Pharmacia, Uppsala, Sweden. Non-radioactive DL-selenomethionine was bought from Calbiochem, Los Angeles, USA.

The 4 animals used were 1-2 years old male sheep of Swedish "lantras" type, weighing between 30 and $40 \mathrm{~kg}$. They were fed hay, $1 \mathrm{~kg}$, straw, $1 \mathrm{~kg}$, grain, $2 \mathrm{hg}$, and wheat bran, $1 \mathrm{hg}$ daily, from 2 months before and during the experimental period.

When the experiment started, $0.2 \mathrm{mCi}$ of $\mathrm{Se}^{75}$-sodium selenite corresponding to $0.2 \mathrm{mg}$ of selenium was injected subcutaneously in ram no. 1 (body weight $40 \mathrm{~kg}$ ) and ram no. 2 (body weight $30 \mathrm{~kg}$ ). Another equally large $\mathrm{Se}^{75}$-dose was injected in the same way on the 37th day in ram no. 1. As shown in Figs. 1 and 2, repeated subcutaneous injections of non-radioactive sodium selenite were given to the animals in a dose of $0.06-0.13 \mathrm{mg}$ of selenium per $\mathrm{kg}$ body weight.

$0.1 \mathrm{mCi}$ of $\mathrm{Se}^{75}$-L-selenomethionine corresponding to $7 \mu \mathrm{g}$ of selenium was injected subcutaneously in rams no. 3 (body weight $34 \mathrm{~kg}$ ) and no. $4^{\prime}$ (body weight $32 \mathrm{~kg}$ ). On the 6th day after this administration subcutaneous injections of sodium selenite were given to the rams in a dose of $0.13 \mathrm{mg}$ of selenium per $\mathrm{kg}$ body weight. On the 10th day, DL-selenomethionine was administered subcutaneously in a dose of $0.13 \mathrm{mg}$ selenium per kg (Fig. 3).

After injection of the respective solutions, urine was collected at varying intervals (Figs. 1, 2 and 3). For this purpose the rams were placed in a box and fitted with rubber bags from which the urine was drawn into collecting vessels. The latter were emptied once or twice a day and the volume of urine was measured. The feces from ram no. 2 was collected during 11 days (Fig. 2a) and from rams nos. 3 and 4 during 13 days (Fig. 4) after the injections of the $\mathrm{Se}^{75}$-doses. The feces was weighed out once or twice a day and about $20 \mathrm{~g}$ from each sample were finely ground. Approximately $2 \mathrm{~g}$ were finally weighed out for measurement of the amount of radioactive selenium. The radioactivity was measured in an auto-gamma spectrometer (Packard). The measurements were made on specimens of $2.0 \mathrm{ml}$ of urine and about $2 \mathrm{~g}$ of feces.

Urine, about $100 \mathrm{ml}$, from some of the samples was taken for chemical analysis of selenium, using a fluorometric method (Lindberg 1968). 


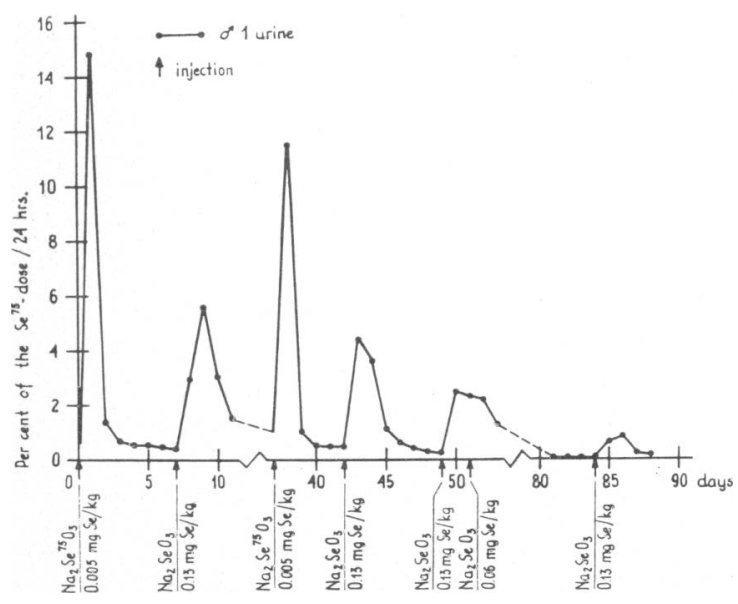

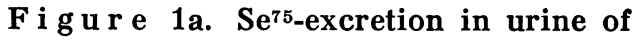
ram no. 1 expressed as a percentage of the $\mathrm{Se}^{75}$-dose per $24 \mathrm{hrs}$. $\mathrm{Se}^{75}$ was injected subcutaneously as $\mathrm{Se}^{75}$-sodium selenite on the 1st and 37th days.

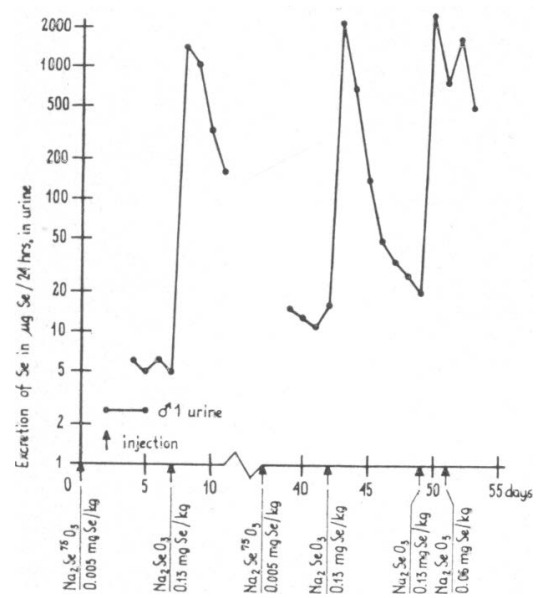

Figure 1b. Excretion of selenium in urine of ram no. 1 . Selenium was determined by the fluorometric method.

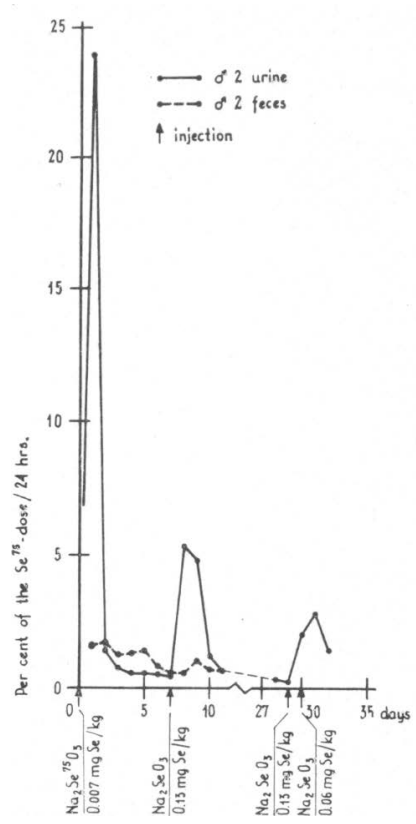

Figure 2a. Se ${ }^{75}$-excretion in urine and feces of ram no. 2 expressed as a percentage of the $\mathrm{Se}^{75}$-dose per $24 \mathrm{hrs}$. $\mathrm{Se}^{75}$ was injected subcutaneously as $\mathrm{Se}^{75}$ sodium selenite on the 1st day.

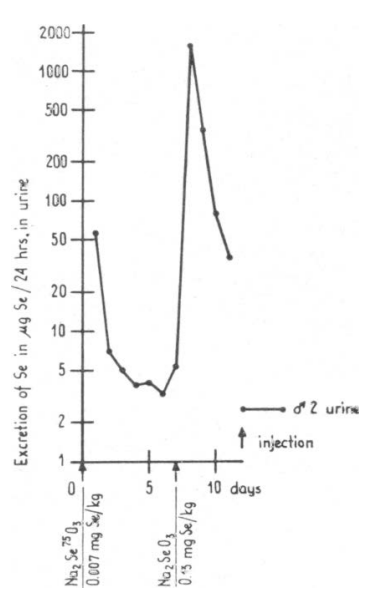

Figure 2b. Excretion of selenium in urine of ram no. 2. Selenium was determined by the fluorometric method. 


\section{RESULTS}

After injection of $\mathrm{Se}^{75}$-sodium selenite as a tracer dose the urinary excretion of $\mathrm{Se}^{75}$ was highest during the first 24 hrs. (Figs. 1a and 2a). It decreased during the following 2 days, and from day 3 and onwards it remained on a low, fairly constant

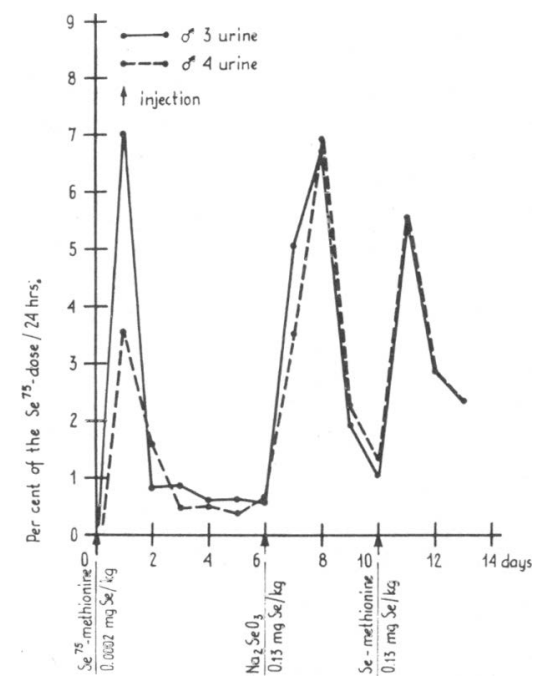

F i g u r e 3a. Se ${ }^{75}$-excretion in urine of rams nos. 3 and 4 expressed as a percentage of the $\mathrm{Se}^{75}$-dose per $24 \mathrm{hrs}$. $\mathrm{Se}^{75}$ was injected subcutaneously as $\mathrm{Se}^{75}$-methionine on the 1 st day.

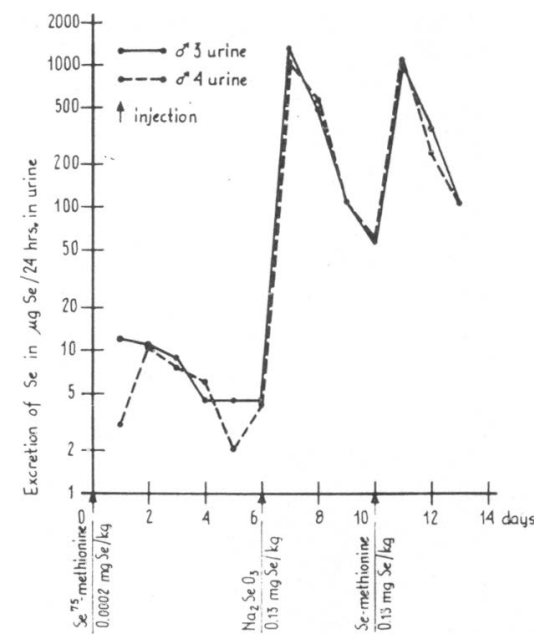

F i g u r e 3b. Excretion of selenium in urine of rams nos. 3 and 4 . The selenium determinations were made by the fluorometric method. 
level. Within the first 3 days after the $\mathrm{Se}^{75}$-injection the excretion in the urine of the 2 rams averaged $19 \%$ of the $\mathrm{Se}^{75}$-dose.

The "flushing doses" of selenium as sodium selenite were injected between 5 and 47 days after the injection of $\mathrm{Se}^{75}$-sodium selenite. Each "flushing dose" increased the urinary excretion of $\mathrm{Se}^{75}$ significantly for about 4 days (Figs. 1a and 2a). The increase was calculated to be $10 \%$ of the $\mathrm{Se}^{75}$-dose after the first "flushing dose" and $3 \%$ after the last one. The rams excreted on an average 10 times more $\mathrm{Se}^{75}$ via the urine during the $24 \mathrm{hrs}$. following such a dose than during the same period of time before it.

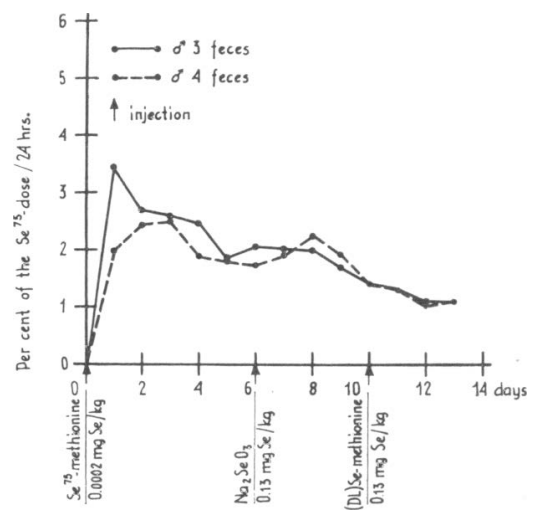

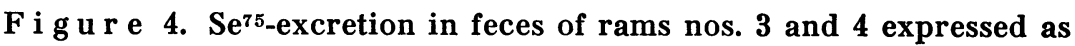
a percentage of the $\mathrm{Se}^{75}$-dose per $24 \mathrm{hrs}$. $\mathrm{Se}^{75}$ was injected subcutaneously as $\mathrm{Se}^{75}$-methionine on the 1 st day.

After injection of $\mathrm{Se}^{75}$-L-selenomethionine the urinary $\mathrm{Se}^{75_{-}}$ excretion was highest during the first $24 \mathrm{hrs}$. Then it decreased during 1 or 2 days and thereafter it was fairly constant (Fig. 3a). On the first 3 days the rams excreted an average of $7 \%$ of the $\mathrm{Se}^{75}$-dose via the urine. After a "flushing dose" of sodium selenite or selenomethionine the $\mathrm{Se}^{75}$-excretion in urine was 5 to 9 times higher in the first $24 \mathrm{hrs}$. than in the same period of time before the injection. The $\mathrm{Se}^{75}$-excretion was elevated for about 4 days after the injection of a "flushing dose" (Fig. 3a). The increase was 11 to $15 \%$ of the $\mathrm{Se}^{75}$-dose.

Figs. $1 \mathrm{~b}-3 \mathrm{~b}$ and $1 \mathrm{a}-3 \mathrm{a}$ demonstrate a close correlation between the concentration of total selenium and radioactive selenium in urine. After the injection of the tracer dose of selenium as $\mathrm{Se}^{75}$-sodium selenite in ram no. 2 the total excretion of selenium 
in urine was $34 \%$ of this dose during 3 days. When the first dose of sodium selenite was injected as a "flushing dose", the corresponding figure for the 4 rams averaged $47 \%$. With a "flushing dose" of selenium as selenomethionine, the total excretion of selenium in urine was about $35 \%$ of the dose during 3 days.

The $\mathrm{Se}^{75}$-excretion in feces rose to maximal values within 1 or 2 days (Figs. 2a and 4). Then it decreased fairly constantly and was not markedly influenced by the "flushing dose" of selenium as sodium selenite or selenomethionine.

\section{DISCUSSION}

It has been demonstrated earlier that a great amount of selenium administered to sheep (Rosenfeld \& Eppson 1964, Jacobsson 1966) and other animals (e.g. Smith et al. 1938, McConnell et al. 1960) is rapidly bound to body proteins. The present investigation has shown that after injection of radioactive selenium as $\mathrm{Se}^{75}$-sodium selenite or $\mathrm{Se}^{75}$-L-selenomethionine, the urinary excretion of $\mathrm{Se}^{75}$ could be increased by injection of non-radioactive selenium. In sheep on a conventional ration the $\mathrm{Se}^{75}$-concentration in the tissues decreases slowly 2 days after administration (Jacobsson). The increased $\mathrm{Se}^{75}$-excretion initiated by the "flushing dose" in the present work indicates that the exchange of selenium from the storage sites can be accelerated by injection of selenium. It may be concluded that the binding of selenium to tissue protein is weak. This conclusion is also supported by a comparison of results obtained by other investigators using other methods (Grant et al. 1961, Orstadius \& Aberg 1961, Lindberg \& Lannek 1965). Recently, Ewan et al. (1967) have published similar results. They showed that after the fixed pool of selenium had been established in tissues of rats, the rate of depletion from this pool varied with the selenium intake. They suggested that the free pool would increase with increasing selenium levels, and since the two are in equilibrium, any fixed $\mathrm{Se}^{75}$ entering the free pool would probably be excreted. The present investigation also demonstrated a close correlation between the levels of $\mathrm{Se}^{75}$ and total selenium in urine. The highest concentration of both occurred shortly after the injection of the "flushing dose". During this time the TCA-soluble part of the selenium in the tissues is highest (Rosenfeld \& Eppson; Jacobsson).

After injection of $\mathrm{Se}^{75}$-selenomethionine the excretion of $\mathrm{Se}^{75}$ 
in urine could be increased with a "flushing dose" of selenium both as sodium selenite and as selenomethionine. This indicates that a great deal of $\mathrm{Se}^{75}$ in the tissues was not firmly incorporated in the proteins, although it had been administered as an amino acid.

The question whether the exchange of the fixed pool of $\mathrm{Se}^{75}$ varies between organs cannot be answered on the basis of the present experiments, and will be further investigated. The present results, as well as earlier investigations (Lindberg \& Lannek; Jacobsson) show that the capacity of the animal to store selenium is limited. When the physiological stores are filled, excess selenium will be excreted in a few days. For that reason, human consumption of meat from sheep given a therapeutic single dose of selenite a few days before slaughter does not seem to involve any great hazards.

\section{REFERENCES}

Ekman, L., K. Orstadius \& B. Åberg: Distribution of $\mathrm{Se}^{75}$-tagged sodium selenite in pigs with nutritional muscular dystrophy. Acta vet. scand. 1963, 4, 92-96.

Ewan, R. C., A. L. Pope \& C. A. Baumann: Elimination of fixed selenium by the rat. J. Nutr. 1967, 91, 547-554.

Flodh, H.: Personal communication 1967.

Grant, C. A., B. Thafvelin \& R. Christell: Retention of selenium by pig tissues. Acta pharmacol. (Kbh.) 1961, 18, 285-297.

Jacobsson, S. O.: Metabolism of selenium in sheep and mice studied with Se $\mathrm{S}^{75}$-sodium selenite, $\mathrm{Se}^{75}$-selenomethionine, and $\mathrm{Se}^{75}$ selenocystine. Thesis. Stockholm 1966.

Lindberg, P.: Selenium determination in plant and animal material, and in water. Acta. vet. scand. 1968, Suppl. 23.

Lindberg, P. \& N. Lannek: Retention of selenium in kidneys, liver and striated muscle after prolonged feeding of therapeutic amounts of sodium selenite to pigs. Acta vet. scand. 1965, 6, 217-223.

Lindberg, P. \& E. Tanhuanpää: Retention of selenium in tissues of swine after a single intramuscular administration of sodium selenite. Acta vet. scand. 1965, 6, 268-273.

McConnell, $K$. P.: Distribution and excretion studies in the rat after a single subtoxic subcutaneous injection of sodium selenite containing radioselenium. J. biol. Chem. 1941, 141, 427-437.

McConnell, K. P., C. H. Wabnitz \& D. M. Roth: Time-distribution studies of selenium-75 in dog serum proteins. Tex. Rep. Biol. Med. 1960, $18,438-445$.

Orstadius, $K$. \& B. Aberg: Distribution of Se $\mathrm{e}^{75}$-tagged sodium selenite in pigs. Acta vet. scand. 1961, 2, 60-67. 
Rosenfeld, I. \& H. F. Eppson: Metabolism of selenium in sheep. Bull. Wyoming agric. exp. Sta. 1964, 414, 53-64.

Schilling, R. F.: A new test for intrinsic factor activity. J. Lab. clin. Med. 1953, 42, 946-947.

Smith, M. I., B. B. Westfall \& E. F. Stohlman: Studies on the fate of selenium in the organism. Publ. Hlth Rep. (Wash.) 1938, 53, $1199-1216$.

Spencer, H., M. Roque, M. Li \& J. Samachson: The effect of stable strontium on radiostrontium metabolism in man. Fed. Proc. 1961, $20,290$.

\section{SUMMARY}

The influence of injected selenium on the excretion of radioactive selenium stored in the body was studied in 4 male sheep. At the beginning of the experiment, radioactive selenium as $\mathrm{Se}^{75}$-sodium selenite and $\mathrm{Se}^{75}$-L-selenomethionine was injected subcutaneously, each compound in 2 rams. The injection of $\mathrm{Se}^{75}$-sodium selenite was repeated in one ram after 37 days. Non-radioactive selenium as sodium selenite or DL-selenomethionine was injected between 5 and 47 days after the injection of the $\mathrm{Se}^{75}$-dose. Each injection of non-radioactive sodium selenite increased the urinary $\mathrm{Se}^{75}$-excretion on an average 10 times. A close correlation was demonstrated between the concentration of $\mathrm{Se}^{75}$ and total selenium in urine.

After the subcutaneous injection of $\mathrm{Se}^{75}$-L-selenomethionine the $\mathrm{Se}^{75}$-excretion in urine was increased both with a "flushing dose" of sodium selenite and with DL-selenomethionine. The concentration of $\mathrm{Se}^{75}$ and that of total selenium in urine of these animals were closely correlated.

$\mathrm{Se}^{75}$-excretion in feces was not markedly influenced by the administration of non-radioactive selenium.

\section{ZUSAMMENFASSUNG}

Die Einwirkung einer "flushing dose" von Selen auf die Ausscheidung von Selen bei Schafen.

Die Einwirkung von parenteral gegebenem Selen auf die Ausscheidung von im Körper vorhandenem radioaktivem Selen wurde bei 4 Schafen männlichen Geschlechts untersucht. Zu Anfang der Versuche wurde radioaktives Selen in der Form von $\mathrm{Se}^{75}$-Natriumselenit und $\mathrm{Se}^{75}$-L-Selenmetionin subkutan in je 2 Schafsböcken injiziert. Die Injektion von Se ${ }^{75}$-Natriumselenit wurde nach 37 Tagen bei einem der Schafsböcke wiederholt. Zwischen 5 und 47 Tagen nach der Injektion von radioaktivem Selen wurde nicht-radioaktives Selen in der Form von Natriumselenit oder DL-Selenmetionin subkutan injiziert.

Bei den Tieren, die Injektionen von Se ${ }^{75}$-Natriumselenit erhalten hatten, erhöhte sich die Ausscheidung von $\mathrm{Se}^{75}$ mit dem Urin wesentlich nach jeder folgenden Injektion von nicht-radioaktivem Natrium- 
selenit. Eine gute Korrelation bestand zwischen der $\mathrm{Se}^{75}$-Konzentration und der totalen Selenkonzentration im Urin.

Injektionen von sowohl Natriumselenit wie DL-Selenmetionin steigerten die Ausscheidung von $\mathrm{Se}^{75}$ im Urin bei den Schafen, die Injektionen von $\mathrm{Se}^{75}$-L-Selenmetionin erhalten hatten. Auch bei diesen war die Se ${ }^{75}$-Konzentration korreliert zur totalen Selenkonzentration.

Die Ausscheidung von $\mathrm{Se}^{75}$ im Kot wurde nicht bemerkenswert von dem zugeführten, nicht radioaktiven Selen beeinflusst.

\section{SAMMANFATTNING}

Inverkan av en „flushing dose“ av selen på utsöndringen av selen hos får.

Parenteralt tillfört selens inverkan på utsöndringen av i kroppen befintligt radioaktivt selen undersöktes hos 4 får av hankön. Vid försökets början injicerades radioaktivt selen $\mathrm{i}$ form av $\mathrm{Se}^{75}$-natriumselenit och $\mathrm{Se}^{75}$-L-selenmetionin subkutant på vardera 2 baggar. Injektionen av $\mathrm{Se}^{75}$-natriumselenit upprepades på en av baggarna efter 37 dygn. Mellan 5 och 47 dygn efter injektionen av det radioaktiva selenet injicerades icke radioaktivt selen $i$ form av natriumselenit eller DLselenmetionin subkutant.

Hos de djur, som erhållit injektioner av $\mathrm{Se}^{75}$-natriumselenit, ökade utsöndringen av $\mathrm{Se}^{75}$ med urinen kraftigt efter varje efterföljande injektion av icke radioaktivt natriumselenit. God korrelation förelåg

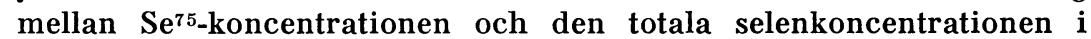
urinen.

Både injektioner av natriumselenit och DL-selenmetionin ökade $\mathrm{Se}^{75}$-utsöndringen $\mathrm{i}$ urinen hos de får som erhållit injektioner av $\mathrm{Se}^{75_{-}}$ L-selenmetionin. Även hos dessa var Se ${ }^{75}$-koncentrationen korrelerad till den totala selenkoncentrationen.

Se $^{75}$-utsöndringen $i$ träcken påverkades inte påtagligt av det tillförda icke radioaktiva selenet.

(Received March 12, 1968). 